\title{
Under the Rainbow
}

\section{Light the Way Grant Focuses on LGBT Families}

\author{
MEEAN ROBERTS
}

$\mathrm{I}$ t seems the best projects begin with a simple conversation, an idea mentioned in passing. For me and Erin Iannacchione, this is exactly how Family Story Time started.

In 2012, I approached Erin about marketing public library summer reading programs to the families and young children at the LGBT Center of Raleigh Library only to find out they didn't have any offerings for families and children. Soon I was planning our very first storytime.

The LGBT Center, where the library is housed, is located in downtown Raleigh and mostly serves the community of the Raleigh-Durham Research Triangle, a metropolitan area of some two million people. As one of the few centers in the state, the LGBT center attracts people from several hours away, but no geographic or economic data is collected for privacy reasons. We knew there were families with young kids in the area, but we didn't have hard demographics information to go on. So we started out small, offering one storytime per quarter for families with children ages birth to six.

There was a small donated collection of children's books, and we started with the idea of reading one positive LGBT book and one seasonal or silly book from the public library. With a makeshift flannel board and a little boom box, we kicked off the first program in fall 2012.

I knew we were onto something when, at a storytime, I asked the kids to raise their hands if they had at least one mommy. One girl at the front shouted, "I have two mommies, and I'm the only one."

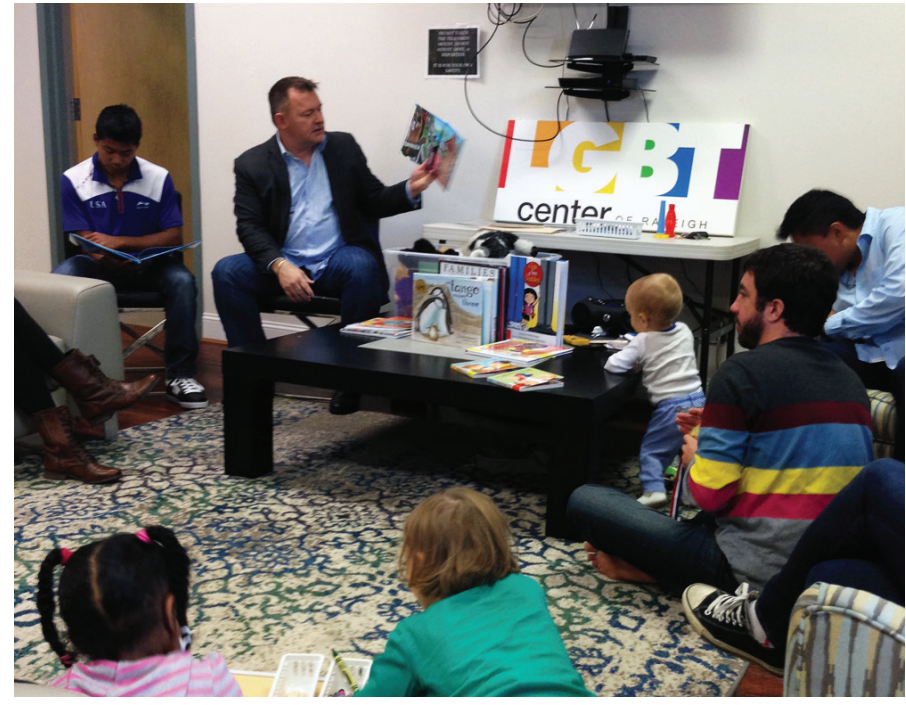

Jerry Windle, co-author of the children's book An Orphan No More, reads to storytime guests along with his son, Jerry, at left.

When I asked kids to raise their hands if they had two mommies, almost every kid behind this little girl raised their hands. The girl was blown away. This little girl proved what we had thought all along, that most LGBT families with young children did not have a chance to interact or connect at a formal event.

But without resources, our program could not expand. Because our entire collection was donated, we were missing important resources about adoption and gender identity and were lacking adequate books on LGBT families. We also needed storytime supplies like puppets, a real flannel board, and more craft supplies than a box of crayons.

When Erin learned about the Candlewick Press Light the Way Grant in fall 2013, we decided to apply despite not having a lot of time before the deadline. We never thought we would receive that grant the first time around, but for a team with no budget to speak of, $\$ 3,000$ was a lot of money.

Since we felt ready to expand, it was easy designing a program for the grant. We had three simple goals: increase our program

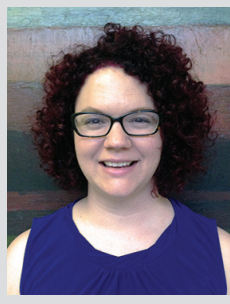

Megan Roberts is Family Story Time Program Director at the LGBT Center of Raleigh (N.C.) Library. 
offering to once a month, buy books and supplies, and market and publicize the program.

We set aside half our budget for collection materials, including books and DVDs. We also wanted to make sure we had resources available to parents on an array of diverse topics, such as parenting a transgender child, navigating adoption, and dealing with bullying.

The other half of the budget was split between marketing and supplies, such as craft supplies, puppets, and refreshments for special storytimes.

The last quarter of our budget was reserved for marketing; we purchased business cards with storytime dates, ads in the local independent paper, and even targeted Facebook ads. As a nonprofit organization, we were not able to afford paid marketing in the past, but we felt it was important to publicize this new program.

We narrowed our choices to 104 books and six DVDs. These materials, along with additional titles donated by Candlewick Press (cosponsor of the grant), make up 80 percent of our current children's collection.

Once we purchased supplies and began our grant funded program, the program itself did not change much. We still offered a storytime with books (including at least one LGBT-themed book), songs, flannelboards, and activities. Since we increased our storytimes to once a month, we brought another volunteer on board.

While our collection quadrupled thanks to the grant, the most profound change has been the ability to market and promote our offerings to the community at large. every family who attended a library program to leave with a broader network of other LGBT families, a sense of affirmation, and connections that extend beyond our program.

As of the end of 2014, we had run ads in the LGBT issue of the area's independent weekly newspaper as well as targeted ads on Facebook.

In December, we even had a

Our goals were pretty simple and straightforward, but our hope for the program was much loftier. We wanted every family who attended a library program to leave with a broader network of other LGBT families, a sense of affirmation, and connections that extend beyond our program. All families benefit from spending time together, and we hope our storytime will be another way families can spend time together and create stronger bonds for the challenges that being in a minority population brings.

\section{Beginning our Collection Development}

We focused on classic titles as well as books about LGBT families, gender nonconforming, being different, self-confidence, bullying, and parenting resources.

Many books on these topics are from smaller presses or had limited copies printed, so many of the books we wanted to purchase from Jamie Campbell Naidoo's resource book, Rainbow Family Collections: Selecting and Using Children's Books with Lesbian, Gay, Bisexual, Transgender, and Queer Content, were unavailable or out of print despite his book being published in $2012 .^{1}$

This was really the only resource book available, so we also scoured blogs, articles, and lists for the newest and latest available titles that are must-haves for a small collection. mom come with her son who didn't know what LGBT stood for but had seen storytime for kids advertised. This was a great opportunity for me to explain all about the community and the types of things we did at storytime. We have also had families attend who had not even heard of the LGBT Center of Raleigh, and they were ecstatic to meet other members of the community.

Currently, we only have women (lesbians and straight allies) with their children attending our storytimes, but I would love to see dads or grandparents attending.

Attendance in general is in flux monthly. We realize we still have some grassroots marketing to do in order to build up program attendance. But overall, we feel lucky to have received the grant to reach this important, yet sometimes overlooked, constituency. \&

\section{Reference}

1. Jamie Campbell Naidoo, Rainbow Family Collections: Selecting and Using Children's Books with Lesbian, Gay, Bisexual, Transgender, and Queer Content (Santa Barbara, Calif.: Libraries Unlimited, 2012). 